\title{
KESESUAIAN BESAR PORSI NASI YANG DISAJIKAN DENGAN STANDAR PORSI PADA MENU MAKANAN BIASA
}

\author{
Sundusil Arsyih ${ }^{1 *}$, Reni Sofiyatin ${ }^{1}$, Suhaema ${ }^{1}$ dan Luh Suranadi ${ }^{1}$ \\ ${ }^{1}$ Jurusan Gizi, Poltekkes Kemenkes Mataram, Indonesia \\ Jalan Praburangkasari Dasan Cermen, Sandubaya Kota Mataram \\ Telp./Fax. (0370) 633837, \\ Email : sundusi12207@gmail.com
}

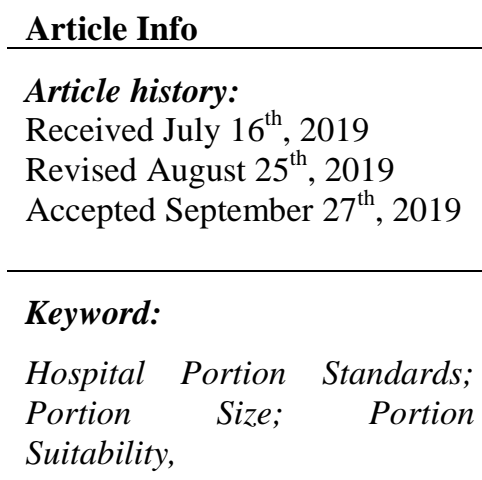

\begin{abstract}
Background. Large portions are often wrong when serving food for patients in hospitals, especially in food serving. There is still an excess and lack of food portions in the hospital because there is no right size in the consumption of rice. This food consumption must be in accordance with the standard portions that have been set. The portion of rice will have a direct effect on the nutritional value contained in food, especially on the nutritional value of carbohydrates which contribute a considerable amount of energy. The purpose of this study was to find out the standard portions, large portions and standard suitability of portions of rice with large portions of rice served at Sanjiwani Hospital Gianyar Regency.
\end{abstract}

Research Methods. The method used in this research is descriptive observational method with crossectional approach.

Research Result. The study was conducted on April 22-24 2019 in Sanjiwani General Hospital, Gianyar Regency with a total sample of 30 servings of rice served on a regular food menu which was observed in 3 servants. The proportion of portions served is measured by the food weighing method for 3 days. The results of this study indicate that the average portion of rice produced by SL servitude is 182.2 grams, IKW is 200.6 grams and $K W$ is 176.3 grams. So that it can be concluded that the suitability of the portion of rice served by 3 average servings is not suitable because it is less than the standard portion.

Copyright $@$ J Jurnal Gizi Prima All rights reserved.

\section{PENDAHULUAN}

Penyelenggaran makanan Rumah Sakit merupakan rangkaian kegiatan mulai dari perencanaan menu, perencanaan kebutuhan bahan makanan, perencanaan anggaran belanja, pengadaan bahan makanan, distribusi dan pencatatan, pelaporan serta evaluasi (Kemenkes RI, 2013). Sedangkan Depkes (2003) menjelaskan bahwa penyelenggaraan makanan adalah rangkaian kegiatan mulai dari perencanaan menu sampai dengan pendListribusian makanan kepada konsumen dalam rangka pencapaian status gizi yang optimal melalui pemberian makanan yang tepat termasuk kegiatan pencatatan, pelaporan, dan evaluasi bertujuan untuk mencapai status kesehatan yang optimal melalui pemberian makan yang tepat.

Setiap proses penyelenggaraan makanan sangat mempengaruhi jumlah dan standar porsi yang dihasilkan. pembelian bahan makanan harus disesuaikan dengan menu, jumlah dan standar porsi yang direncanakan. Menurut Muchatob (2001) dalam Astuti (2018) menyatakan bahwa standar porsi dapat diartikan sebagai banyaknya makanan yang disajikan dan ukuran porsi untuk setiap individu. Untuk menentukan besar porsi yang akan disajikan kepada konsumen agar konsumen mendapatkan makanan yang sesuai dengan kebutuhan 
zat gizi baik dari segi kualitas suatu makanan maka dibutuhkan juga penyusunan standar porsi yang digunakan sebagai salah satu acuan. Oleh sebab itu untuk mencapai hal tersebut, maka setiap institusi penyelenggaraan makan harus menentukan standar porsi dari setiap makanan yang akan disajikan.

Menurut penelitian Ambarwati (2016) besar porsi seringkali menjadi hal yang salah saat menyajikan makanan, terutama dalam pemorsian makanan. Masih terjadi kelebihan dan kekurangan porsi karena tidak ada ukuran yang tepat dalam pemorsian makanan pokok. Pemorsian makanan ini harus sesuai dengan standar porsi yang telah ditentukan oleh pihak instalasi gizi rumah sakit. Besar porsi akan berpengaruh langsung tehadap nilai gizi yang terkandung dalam suatu makanan.

Dalam penelitian Wadyomukti (2017) di Rumah Sakit Muhammadiyah Bantul bahwa hasil pengamatan dan penimbangan pada pemorsian makanan pokok nasi yang diporsikan oleh tenaga pemorsi Instalasi Gizi dengan toleransi ketepatan pemorsian sebesar 10\%, menunjukkan bahwa masih ada berat porsi yang tidak tepat porsi terhadap standar porsi yang telah ditetapkan di Instalasi Gizi, dimana persentase ketepatan porsi dari setiap tenaga pemorsi masih terdapat pemorsian yang tidak tepat sebesar $36 \%$.

Berdasarkan penelitian Astuti (2018) bahwa Kesesuaian standar porsi makan pada makanan pokok (nasi) untuk pasien rawat inap kelas III yang disajikan untuk menu makan siang di RSUD Bahteramas Provinsi Sulawesi Tenggara yaitu 100\% dikategorikan kurang. Rata-rata besar porsi makanan pokok yang disajikan adalah sebesar 161,67 gram (80,8 \%). Hal ini disebabkan karena pramusaji di instalasi gizi RSUD Bahteramas Kota Kendari tidak perpatokan pada standar porsi nasi yang telah ditetapkan yaitu sebesar 200 gram. Oleh sebab itu sangat diperlukan observasi untuk melihat kesesuaian standar porsi yang ditetapkan dengan yang disajikan pada pasien di rumah sakit.

Dari penjelasan di atas, maka penulis tertarik melakukan penelitian tentang "Gambaran kesesuaian besar porsi nasi yang disajikan dengan standar porsi pada menu makanan biasa ".

Tujuan dari penelitian ini yaitu untuk mengetahui gambaran kesesuaian besar porsi yang disajikan dengan standar porsi pada menu makanan biasa di Rumah Sakit Sanjiwani Kabupaten Gianyar.

\section{METODE PENELITIAN}

Penelitian dilakukan dengan metode observasional deskriptif dengan pendekatan crossectional dimana untuk memperoleh gambaran kesesuaian besar porsi nasi yang disajikan dengan standar porsi. Penelitian dilakukan di instalasi gizi RSUD Sanjiwani Kabupaten Gianyar pada tanggal 22, 23, dan 24 April 2019. Subjek yang digunakan adalah tenaga pemorsi selama 3 hari yang berjumlah 3 orang. Objek yang digunakan adalah nasi yang disajikan oleh tenaga pemorsi pada menu makanan biasa selama 3 hari penelitian.

Data primer meliputi data karakteristik tenaga pemorsi dan data hasil penimbangan nasi. Data sekunder meliputi gambaran umum penyelenggaraan makanan dan standar porsi makanan rumah sakit. Data tentang karakteristik tenaga pemorsi dikumpulkan dengan cara wawancara langsung. Data tentang porsi nasi yang disajikan pada menu makanan biasa dikumpulkan dengan melakukan food weighing dengan menggunakan alat bantu timbangan digital dengan pengambilan sampel sebanyak 10 porsi dalam sehari. Data kesesuaian besar porsi nasi yang disajikan dengan standar porsi dianalisis secara deskriptif dan disajikan dalam bentuk tabel frekuensi dan narasi.

\section{HASIL PENELITIAN}

Rumah Sakit Umum Daerah Sanjiwani Kanupaten Gianyar memiliki satu unit instalasi gizi yang bertugas untuk menyediakan kebutuhan makan pasien. Proses penyelenggaraan makanan untuk pasien dimulai dari proses penerimaan hingga proses distribusi makanan dari tempat produksi hingga ke kamar pasien, dengan mengggunakan sistem distribusi sentralisasi.

Dalam pemorsian, instalasi gizi RSUD Sanjiwani Kabupaten Gianyar memiliki ketentuan penyajian berdasarkan kelas dan diet pasien. Untuk pemorsian makanan ke pasien, instalasi gizi RSUD Sanjiwani Kabupaten Gianyar memiliki standar porsi makanan untuk pasien. Untuk standar porsi nasi sebesar 312,5 gram (125 gram beras). 
Karakteristik Subyek Penelitia

Tabel 1. Karakteristik Tenaga Pemorsi Berdasarkan Jenis Kelamin, Pendidikan, dan Lama Bekerja

\begin{tabular}{ccccc}
\hline No & Nama & Jenis kelamin & Pendidikan & Lama bekerja \\
\hline 1. & SL & Perempuan & S1 Hukum & 10 tahun \\
2. & IKW & Laki-laki & D III Gizi & 9 tahun \\
3. & KW & Laki-laki & D I Gizi & 18 tahun \\
\hline
\end{tabular}

Berdasarkan tabel 1 di lihat dari jenis kelamin, jumlah tenaga pemorsi yaitu sebanyak 2 orang laki-laki dan 1 orang perempuan. Dari pendidikan, rata-rata tenaga pemorsi memiliki pendidikan yang dikategorikan tinggi. Berdasarkan lama bekerja, dari 3 tenaga pemorsi yang memorsikan nasi terdapat 2 tenaga pemorsi yang termasuk lama bekerja dan 1 tenaga pemorsi yang masih termasuk baru bekerja.

Kesesuaian porsi nasi yang disajikan terhadap standar porsi di RSUD Sanjiwani Kabupaten Gianyar Pengamatan Hari Ke-1 Oleh Tenaga SL

Tabel 2. Kesesuaian Besar Porsi Nasi Yang Disajikan Oleh Tenaga SL

\begin{tabular}{ccccc}
\hline Obyek & $\begin{array}{c}\text { Berat matang } \\
(\text { gram })\end{array}$ & $\begin{array}{c}\text { Standar porsi } \\
(\text { gram })\end{array}$ & Keterangan & Persentase $(\%)$ \\
\hline 1 & 158 & 312,5 & Tidak sesuai & 50,6 \\
2 & 213 & 312,5 & Tidak sesuai & 68,2 \\
3 & 227 & 312,5 & Tidak sesuai & 72,6 \\
4 & 173 & 312,5 & Tidak sesuai & 55,4 \\
5 & 166 & 312,5 & Tidak sesuai & 53,1 \\
6 & 172 & 312,5 & Tidak sesuai & 55,0 \\
7 & 177 & 312,5 & Tidak sesuai & 56,6 \\
8 & 182 & 312,5 & Tidak sesuai & 58,2 \\
9 & 171 & 312,5 & Tidak sesuai & 54,7 \\
10 & 183 & 312,5 & Tidak sesuai & 58,6 \\
Rata-rata & 182,2 & 312,5 & Tidak sesuai & 58,3 \\
\hline
\end{tabular}

Berdasarkan hasil pengamatan dan penimbangan pada pemorsian nasi yang diporsikan oleh tenaga pemorsi SL menunjukkan bahwa 10 sampel nasi yang diporsikan tidak sesuai dengan standar porsi yang telah ditetapkan. Ketidaksesuaian porsi nasi ini dikarenakan berat nasi yang dihasilkan rata-rata kurang dari standar porsi yang telah ditetapkan oleh instalasi gizi. Persentase rata-rata berat nasi yang diporsikan oleh tenaga pemrosi SL yaitu 58,3\% dengan persentase tertinggi sebesar 72,6 \% dan terendah sebesar 50,6\%.

\section{Pengamatan Hari Ke-2 Oleh Tenaga IKW}

Tabel 3. Kesesuaian Besar Porsi Nasi Yang Disajikan Oleh Tenaga IKW

\begin{tabular}{ccccc}
\hline Obyek & $\begin{array}{c}\text { Berat matang } \\
(\text { gram })\end{array}$ & $\begin{array}{c}\text { Standar porsi } \\
(\text { gram })\end{array}$ & Keterangan & Persentase $(\%)$ \\
\hline 1 & 232 & 312,5 & Tidak sesuai & 74,2 \\
2 & 197 & 312,5 & Tidak sesuai & 63,0 \\
3 & 219 & 312,5 & Tidak sesuai & 70,1 \\
4 & 237 & 312,5 & Tidak sesuai & 75,8 \\
5 & 199 & 312,5 & Tidak sesuai & 63,7 \\
6 & 184 & 312,5 & Tidak sesuai & 58,9 \\
7 & 199 & 312,5 & Tidak sesuai & 63,7 \\
8 & 171 & 312,5 & Tidak sesuai & 54,7 \\
9 & 180 & 312,5 & Tidak sesuai & 57,6 \\
10 & 188 & 312,5 & Tidak sesuai & 60,2 \\
Rata-rata & 200,6 & 312,5 & Tidak sesuai & 64,2 \\
\hline
\end{tabular}


Berdasarkan hasil pengamatan dan penimbangan pada pemorsian nasi yang diporsikan oleh tenaga pemorsi IKW menunjukkan bahwa 10 sampel nasi yang diporsikan tidak sesuai dengan standar porsi yang telah ditetapkan. Ketidaksesuaian porsi nasi ini dikarenakan berat.

nasi yang dihasilkan rata-rata kurang dari standar porsi yang telah ditetapkan oleh instalasi gizi. Persentase rata-rata berat nasi yang diporsikan oleh tenaga pemrosi IKW yaitu 64,2\% dengan persentase tertinggi sebesar $74,2 \%$ dan terendah sebesar $54,7 \%$.

\section{Pengamatan Hari Ke-3 Oleh Tenaga KW}

Tabel 4. Kesesuaian Besar Porsi Nasi Yang Disajikan Oleh Tenaga IKW

\begin{tabular}{ccccc}
\hline Obyek & $\begin{array}{c}\text { Berat matang } \\
(\text { gram })\end{array}$ & $\begin{array}{c}\text { Standar porsi } \\
(\text { gram })\end{array}$ & Keterangan & Persentase $(\%)$ \\
\hline 1 & 171 & 312,5 & Tidak sesuai & 54,7 \\
2 & 170 & 312,5 & Tidak sesuai & 54,4 \\
3 & 157 & 312,5 & Tidak sesuai & 50,2 \\
4 & 181 & 312,5 & Tidak sesuai & 57,9 \\
5 & 174 & 312,5 & Tidak sesuai & 55,7 \\
6 & 163 & 312,5 & Tidak sesuai & 52,2 \\
7 & 177 & 312,5 & Tidak sesuai & 56,6 \\
8 & 182 & 312,5 & Tidak sesuai & 58,2 \\
9 & 203 & 312,5 & Tidak sesuai & 65,0 \\
10 & 185 & 312,5 & Tidak sesuai & 59,2 \\
Rata-rata & 176,3 & 312,5 & Tidak sesuai & 56,4 \\
\hline
\end{tabular}

Berdasarkan hasil pengamatan dan penimbangan pada pemorsian nasi yang diporsikan oleh tenaga pemorsi KW menunjukkan bahwa 10 sampel nasi yang diporsikan tidak sesuai dengan standar porsi yang telah ditetapkan. Ketidaksesuaian porsi nasi ini dikarenakan berat nasi yang dihasilkan rata-rata kurang dari standar porsi yang telah ditetapkan oleh instalasi gizi. Persentase rata-rata berat nasi yang diporsikan oleh tenaga pemrosi KW yaitu 56,4 \% dengan persentase tertinggi sebesar 65,0\% dan terendah sebesar 50,2\%.

Berdasarkan hasil pengamatan, terdapar faktor yang mempengaruhi ketidaksesuaian besar porsi nasi yang disajikan yaitu alat yang digunakan belum terstandar dan keterampilan dari masing-masing tenaga pemorsi dalam melakukan pemorsian nasi yang kurang memperhatikan standar porsi yang telah ditetapkan oleh Rumah Sakit.

\section{PEMBAHASAN}

Berdasarkan hasil pemorsian oleh 3 tenaga pemorsi menunjukkan bahwa tidak ada porsi nasi yang sesuai dengan standar porsi yang telah ditetapkan oleh Rumah Sakit. Persentase rata-rata berat nasi yang dihasilkan oleh tenaga pemorsi yaitu 58,3\% oleh tenaga pemorsi SL, 64,2\% oleh tenaga pemorsi IKW dan 56,4\% oleh tenaga pemorsi KW. Jadi persentase rata-rata berat nasi yang dihasilkan sebesar 59,6\%.

Berdasarkan hasil pengamatan selama 3 hari, ketidaksesuaian besar porsi nasi yang disajikan disebabkan karena beberapa faktor yaitu pada tenaga pemorsi nasi itu sendiri dan alat yang digunakan untuk memorsikan nasi. Ketidaksesuaian standar porsi dari tenaga pemorsi dapat dipengaruhi oleh beberapa hal, seperti pendidikan dan lamanya bekerja.

Keterampilan tenaga pemorsi dalam melakukan pemorsian nasi sangat mempengaruhi kesesuaian porsi disebabkan oleh tenaga pemorsi kurang memperhatikan standar porsi yang telah ditetapkan oleh rumah sakit. Tenaga pemorsi melakukan pemorsian didasarkan faktor kebiasaan dalam melakukan pemorsian nasi serta dipengaruhi oleh waktu pemorsian yang singkat dengan jumlah pemesanan yang banyak.

Hal ini sejalan dengan penelitian Wadyomukti (2017) yang menunjukkan bahwa sebagian besar hasil pemorsian nasi yang tidak tepat sebesar $36 \%$ dimana faktor yang mempengaruhi besar porsi yang tidak tepat 
yaitu keterampilan tenaga pemorsi, alat yang digunakan untuk pemorsian dan jenis dan konsistensi bahan dasar beras yang dimasak.

Berdasarkan penelitian Astuti (2018) menunjukkan bahwa kesesuaian besar porsi makanan pokok pada kelas perawatan II 100\% tidak sesuai dengan standar porsi yang telah ditetapkan oleh rumah sakit. Rata-rata berat makanan pokok yang disajikan yaitu 161,7 gram. Hal ini disebabkan karena pramusaji di instalasi gizi RSU Bahteramas tidak berpatokan pada standar porsi makan rumah sakit walaupun telah menggunakan cetakan nasi, namun cetakan nasi yang digunakan ukurannya belum distandarkan sesuai dengan rata-rata kebutuhan pasien pada umumnya yaitu 100-200 gram.

Alat pemorsian juga dapat mempengaruhi porsi nasi yang tidak sesuai. Oleh karena itu perlu adanya alat pemorsi nasi yang terstandar agar porsi nasi yang dihasilkan sesuai dengan standar porsi yang telah ditetapkan. Akan tetapi, walaupun memakai alat yang sama untuk pemorsian, setiap tenaga pemorsi memiliki perbedaan persepsi dalam memperkirakan besar porsi nasi yang disajikan. Alat pemorsi nasi yang digunakan di RSUD Sanjiwani Kabupaten Gianyar belum di standarisai dengan hasil porsi yang disajikan sehingga menyebabkan besar porsi nasi yang dihasilkan kurang dari standar porsi yang telah ditetapkan

Hal ini sejalan dengan penelitian Wadyomukti (2017) yang melakukan penelitian di RS PKU Muhammadiyah Bantul menunjukkan bahwa alat yang digunakan untuk memporsikan nasi belum terstandar sehingga besar porsi nasi yang disajikan tidak sesuai dengan standar porsi. Hal dikarenakan terdapat perbedaan alat yang digunakan pada saat pemorsian nasi dengan yang tercantum pada standar alat untuk pemorsian nasi. Selain itu, hal ini juga sejalan dengan penelitian Ibadiri (2012) yang melakukan penelitian di RSUD Praya menyatakan bahwa kesesuaian porsi makanan yang disajikan dipengaruhi oleh keterampilan petugas pemorsi dan alat porsi yang digunakan.

Ketidaksesuaian besar porsi nasi yang disajikan dapat mempengaruhi asupan zat gizi pasien. Apabila porsi makanan kurang atau lebih, otomatis nilai gizi makanan pasien berkurang atau berlebih. Berdasarkan hasil penelitian, besar porsi nasi yang disajikan oleh 3 tenaga pemorsi pada menu makanan biasa rata-rata kurang dari standar porsi (312,5 gram) dengan persentase 59,6\%. Hal ini menunjukkan bahwa pasien hanya mendapatkan rata-rata nasi sebesar 186,25 gram dengan nilai gizi sebesar energi 279,4 kkal, protein 6,3 gram, lemak 1,3 gram dan karbohidrat 57,4 gram. Dimana yang seharusnya pasien mendapatkan porsi nasi sesuai dengan standar porsi degan nilai gizi sebesar energi 448,75 kkal, protein 10,5 gram, lemak 2,1 gram dan karbohidrat 96,4 gram. Ketidaksesuaian besar porsi nasi mengakibatkan asupan zat gizi pasien kurang khususnya zat gizi karbohidrat.

Kesesuaian porsi sangat penting dan perlu diperhatikan karena menyangkut asupan zat gizi pasien sejalan dengan pendapat Davies, 2008 dalam Wadyomukti (2017) pada penelitiannya diungkapkan ukuran porsi merupakan salah satu faktor yang menentukan asupan zat gizi. Hal ini juga sejalan dengan penelitian Ambarwati (2016) pada penelitiannya mengungkapkan bahwa standar porsi makanan sangat berperan dalam penyelenggaraan makanan yang dikaitkan dengan nilai gizi makanan. Kesesuaian berat porsi dapat mempengaruhi asupan makan pasien, apabila porsi makanan kurang atau lebih otomatis nilai gizi makanan pasien berkurang atau berlebih sehingga menyebabkan mutu makanan menjadi kurang baik. Sehingga dalam pemorsian makan pasien harus sesuai dengan standar porsi yang telah ditetapkan agar pasien mendapatkan asupan zat gizi sesuai kebutuhan.

Selain itu, ketidaksesuaian porsi juga berakibat pada biaya yang dikeluarkan instalasi gizi menjadi tidak sesuai dengan rencana anggaran. Hal ini sesuai dengan Pedoman Gizi Rumah Sakit tahun 2013 yang menjelaskan tentang Perencanaan Anggaran Bahan Makanan dengan tujuan perencanaan yaitu untuk memenuhi kebutuhan macam dan jumlah bahan makanan bagi konsumen/pasien yang dilayani sesuai dengan standar yang telah ditetapkan. Jika porsi nasi yang digunakan untuk menu tidak sesuai baik lebih tinggi dari standar maupun lebih sedikit dari standar maka akan mempengaruhi kebutuhan gizi dari pasien tersebut. Hal ini dapat menjadi evaluasi bagi rumah sakit agar lebih memperhatikan kesesuaian besar porsi nasi yang disajikan dengan standar porsi yang telah ditetapkan.

\section{KESIMPULAN}

Dari 30 porsi nasi yang disajikan, rata-rata berat porsi nasi yang dihasilkan tidak sesuai dengan standar porsi yang ditetapkan oleh Rumah Sakit. Rata-rata berat nasi yang dihasilkan kurang dari standar porsi yaitu 
312,5 gram. Persentase rata-rata berat nasi yang diporsikan oleh tenaga pemorsi SL yaitu 58,3\%, tenaga pemorsi IKW sebesar 64,2\%, dan tenaga pemorsi KW sebesar 56,4\%. Hal ini menunjukkan bahwa pemorsian nasi di RSUD Sanjiwani Kabupaten Gianyar kurang baik, hal ini disebabkan ketidaksesuaian besar porsi nasi yang disajikan dengan standar porsi masih cukup besar.:2015 menunjukkan bahwa seluruh tenaga pengolah makanan menerapkan personal hygiene dengan baik.

\section{SARAN}

Perlu adanya standarisasi penggunaan alat untuk memporsikan nasi agar porsi nasi yang dihasilkan sesuai dengan standar porsi yang telah ditetapkan. Perlu dilakukan evaluasi terkait penggunaan alat yang standar untuk memporsikan makanan dan evaluasi terkait kesesuaian besar porsi nasi yang disajikan dengan standar porsi yang ditetapkan. Perlu adanya sebuah pelatihan dan sosialisasi untuk tenaga pemorsi makanan agar setiap tenaga pemorsi terampil dalam melakukan pemorsian makanan. Bagi peneliti yang ingin mengambil topi penelitian tentang kesesuaian besar porsi yang disajikan dengan standar porsi, perlu mengkaji tentang pengaruh besar porsi yang disajikan terhadap asupan zat gizi pasien dan biaya dalam penyelenggaraan makanan rumah sakit.

\section{DAFTAR PUSTAKA}

Ahmadi, Djauzak. 2004. Peningkatan Mutu Pendidikan Sebagai Sarana Pembangunan Bangsa. Jakarta: Balai Pustaka.

Almatsier,S.2010.Penuntun Diet.Edisi Terbaru.PT Gramedia Pustaka Utama.Jakarta.Hal.30

Ambarwati,R.2016.Laporan Praktik Kuliah Lapangan (PKL) Menetapkan Standar RS Dan Perhitungan Kebutuhan Bahan Makan RSU Panembahan Senopati Bantu

Ardana, I Komang. Mujiati, Ni Wayan. Utama, I Wayan Mudiarta. 2012. Manajemen Sumber Daya Manusia. Yogyakarta: Graha Ilmu.

Astuti, I.A.E. 2018. Gambaran Kesesuaian Standar Porsi Makan Rumah Sakit Dengan Besar Porsi Yang Disajikan Di Instalasi Gizi RSUD Bahteramas Kota Kendari.Karya Tulis Ilmiah Politeknik Kesehatan Kendari

Bachyar,B.,Intiyati, A., dan Widartika.2018.Sistem Penyelenggaraan Makanan Institusi.

Benowati, R. 2016. Hubungan Tingkat Pendidikan, Pengetahuan Diet dan Masa Kerja Tenaga Distribusi Makanan dengan Ketepatan Pemberian Diet Pasien di RSUD RAA Soewondo Pati. Publikasi Ilmiah. Universitas Muhammadiyah Surakarta.

Chasanah,U.2018.Hubungan Pendidikan, Lama Bekerja dan Pengetahuan tentang Pemorsian Petugas Penjamah Makanan dengan ketepatan Porsi Makan di RSJD Dr. Amino Gondohutomo Provinsi Jawa Tengah

Depkes RI.2003. Pelayanan Gizi Rumah Sakit.Jakarta:Direktorat Rumah Sakit Khusus dan Swasta,Dit.Jen. Yanmedik

Depkes RI.2007. Profil Kesehatan 2007.Departemen Kesehatan RI

Depkes RI.2013. Pelayanan Gizi Rumah Sakit.Jakarta:Departemen Kesehatan Republik Indonesia

Ibadiri. 2012. Kesesuaian berat porsi degan standar porsi dan sisa makanan biasa di Rumah Sakit Umum Daerah Praya Lombok Tengah. Karya Tulis Ilmiah. Politeknik Kesehatan Mataram

Kementerian Kesehatan RI.2013. Pelayanan Gizi Rumah Sakit

Kementerian kesehatan republik Indonesia. Tabel komposisi pangan Indonesia (TKPI) tahun 2017 
Kementerian Kesehatan Republik Indonesia. Badan penelitian dan pengembangan kesehatan tahun 2017 tentang pedoman konversi berat matang-mentah, berat dapat dimakan (BDD) dan resep makanan siap saji dan jajanan

Notoatmodjo,S.2010. Ilmu Perilaku Kesehatan.Jakarta:PT. Rineka Cipta

Permenkes RI No. 41 tahun 2014 tentang pedoman gizi seimbang. Kementerian kesehatan republik Indonesia Rohmi, N.R.2018. Kesesuaian porsi lauk hewani pada penyelenggaraan makan siang pada menu makanan biasa di RSUD Kabupaten Klungkung

Supariasa, D.N., Bakri, B., dan Fajar, I.2002. Penilaian Status Gizi. Jakarta:Penerbit Buku Kedokteran EGC

Wadyomukti,2017.Hubungan Karakteristik Tenaga Pemorsian Dan Alat Pemorsian Dengan Ketepatan Pemorsian Makanan Pokok Berdasarkan Standar Porsi Di Rumah Sakit PKU Muhammadiyah Bantul.Skripsi Politeknik Kesehatan Kemenkes Yogyakarta. 